\title{
MINORITAS MILITAN: SIKAP KOMUNITAS MATIUS TERHADAP ROH KAPITALISME
}

\author{
DEMIANUS NATANIEL ${ }^{1}$
}

\begin{abstract}
Capitalism has evolved since the time of Matthew's own community. Capitalism development was mainly cultivated by the Romans who controlled Antioch as the context of Matthew's own community. The author outlines how communities Matthew emphasizes Jesus' teaching against the adverse effects of Capitalism, like greed to accumulate wealth for themselves without ever attentive to the needs of the poor and oppressed. Community Matthew pushed ideal vision of Jesus that regard the life of this world by structuring society full of peace and prosperity.
\end{abstract}

Kata-Kata Kunci : Komunitas Matius, Minoritas Militan, Kapitalisme, Weber, Duchrow.

1 Dr. Deminius Nataniel merupakan dosen STT Abdiel, Ungaran. 


\section{PENDAHULUAN}

Cepanjang abad terakhir hingga memasuki dua dasa warsa milenium baru Oini, usaha memahami Injil Matius umumnya dipengaruhi oleh pemahaman adanya pertentangan antara komunitas Matius dengan otoritas sinagoge di akhir abad pertama ZB. ${ }^{2}$ Namun demikian, melalui dua karyanya, yakni Matthew and the Margin dan Matthew and Empire, Warren Carter menawarkan perspektif lain, yakni memahami Injil Matius dengan lebih menekankan bagaimana relasi komunitas Matius terhadap kekaisaran Romawi di akhir abad pertama ZB. Berdasarkan asumsi adanya hubungan dialektis antara komunitas Matius dan konteks sosial, politik dan keagamaan masyarakat pada waktu itu, Carter menjelaskan bahwa komunitas Matius sangat dipengaruhi dan lebih jauh lagi menentang kehadiran kekuasaan Romawi yang ada pada waktu itu. Beberapa kosakata yang digunakan oleh Injil Matius, seperti kerajaan (basileia), kuk (zugos), dan terang ( $(\square s)$, menurutnya harus dipahami dalam konteks perlawanan komunitas Matius terhadap kekuasaan Romawi. Selain itu juga harus dipahami bahwa pada waktu itu wilayah keagamaan tidak dapat dipisahkan dari arena politik. ${ }^{3}$ Keduanya saling berkaitan.

Dengan memanfaatkan perspektif yang digunakan Carter dalam memahami Injil Matius, tulisan ini lebih jauh menyoroti sikap komunitas Matius terhadap salah satu pengaruh di bidang sosial, politik dan ekonomi yang dibangun kekaisaran Romawi, yakni mulai menguatnya unsur-unsur kapitalisme, khususnya keserakahan yang terejawantah dalam motivasi penumpukkan harta. Beberapa kisah dalam Injil Matius mencerminkan karakter militan dan perlawanan komunitas Matius terhadap keserakahan dan motif penumpukan harta yang ada di balik faham kapitalisme.

Sebelum mengulas teks-teks dalam Injil Matius yang berhubungan dengan perlawanan komunitas Matius terhadap keserakahan dan motif pengumpulan harta, makalah ini terlebih dahulu membahas secara singkat sejarah kapitalisme. Untuk membuktikan bahwa Injil Matius memuat kisah-kisah yang melawan faham kapitalisme maka dibahas pula situasi dan kondisi kota Antiokhia yang diasumsikan sebagai tempat ditulisnya Injil Matius.

2 Warren Carter, Matthew and Empire: Initial Exploration (Harrisburg, Pennsylvania: Trinity Press Internationa, 2001), 1.

$3 \quad$ Ibid., 5. 
Model penafsiran yang digunakan dalam tulisan ini terutama adalah model penafsiran yang memanfaatkan ilmu-ilmu sosial, yang memahami adanya hubungan dialektis antara komunitas Matius dan konteks sosial masyarakat di sekitarnya, yang tercermin dalam isi dan penuturan Injil Matius. ${ }^{4}$ Dengan penggunaan model penafsiran ini, dipahami pula bahwa kehadiran Yesus adalah personifikasi komunitas Matius yang melahirkan Injil Matius. Sebaliknya, tokohtokoh dan segala sesuatu yang dilawan baik melalui tindakan maupun perkataan Yesus dipahami sebagai simbol baik dari situasi dan kondisi, maupun juga kelompok yang dilawan oleh komunitas Matius. Walaupun pendekatan yang digunakan dalam penafsiran teks-teks Injil Matius di sini lebih menggunakan pendekatan ilmu-ilmu sosial, namun alur naratif Injil Matius tetap diperhatikan. Selain kedua pendekatan yang disebut di atas, penggunaan strategi membaca intertekstual, yang membandingkan teks-teks Injil Matius dengan teks-teks lain, khususnya Injil-injil sinoptik juga dimanfaatkan. ${ }^{5}$

\section{AKAR-AKAR KAPITALISME MODERN}

Kapitalisme secara sederhana dipahami sebagai faham yang meyakini bahwa dengan bertumpu pada kekuatan modal maka usaha dapat dilakukan sebesarbesarnya untuk meraih keuntungan. ${ }^{6}$ Pertanyaannya adalah sejak kapan faham ini mulai menguasai dunia?

Dalam bukunya The Protestant Ethic And The Spirit of Capitalism, Max Weber menghubungkan ajaran predestinasi Calvin dengan pembentukan masyarakat kapitalis di Eropa yang dimulai pada abad ke-17.' Dari penjelasan Weber, ajaran Calvin mengenai predestinasi menghasilkan etos kerja yang secara alamiah mendukung budaya pengumpulan harta di dunia sebagai penyataan diri orangorang yang telah dipilih untuk diselamatkan oleh Allah. Penjelasannya ini bisa saja dipahami sebagai petunjuk bahwa kapitalisme baru dimulai di Eropa pada abad ke-17 ZB. Pertanyaannya adalah apakah sebelumnya tidak ada sama sekali

4 Bdk. David Rhoads, "Social Criticism: Crossing Boundaries, dalam Mark E Methods: New Approaches in Biblical Studies, peny. Jenice C. Anderson \& Stephen D. Moore (Minneapolis: Fortress Press, 1992), 139-141.

5 Bdk. Richard Bauckham, Gospel Women: Studies of the Named Women in the Gospels (London, NY: T\&T Clark, 2002), xix.

6 Bdk. George Soros, Open Society: Reforming Global Capitalism, terj. Dawam Rahardjo (Jakarta: Yayasan Obor Indonesia, 2006), 183-186,

7 Max Weber, The Protestant Ethic And The Spirit of Capitalism, trans. Talcott Parsons (NY: Charles Scribner's Sons, 1958), 98-128. 
bentuk kehidupan yang mendukung terbentuknya masyarakat kapitalis seperti sekarang ini?

Dalam bukunya yang berjudul Mengubah Kapitalisme Dunia, Ulrich Duchrow mengungkapkan bagaimana faham kapitalisme berkembang. ${ }^{8}$ Selain mengajak untuk mewaspadai godaan kapitalisme yang mematikan, ia juga memaparkan asal muasal kapitalisme modern dan kekuatannya yang dahsyat saat ini, termasuk pergeseran pemahaman mengenai apa yang dapat dikategorikan sebagai modal.

Dengan memanfaatkan karya-karya terutama dari Karl Polanyi dan H.C. Binswanger, Duchrow dalam bagian pertama bukunya itu menjelaskan bagaimana para filsuf turut bertanggung jawab dalam membangun kapitalisme. ${ }^{9}$ Untuk itu ia mulai dengan mengulas pemikiran Aristoteles mengenai makna kegiatan ekonomi dan juga peranan pasar. Aristoteles mengingatkan bahwa kegiatan ekonomi dan peran pasar seharusnya menjadi alat pemenuhan kebutuhan hidup manusia, bukan sebagai alat untuk meraih keuntungan. Sayangnya, keduanya mengalami pergeseran akibat keserakahan manusia. Tujuan keduanya bergeser dari yang melayani kebutuhan umat manusia menjadi sarana untuk meraih keuntungan pribadi atau kelompok.

Duchrow kemudian juga mengulas pemikiran Thomas Hobbes dan John Locke yang dianggapnya turut melapangkan kapitalisme dalam menguasai dunia. Dengan membalikkan cara berpikir Aristoteles mengenai konsep pasar dan manusia, mereka memahami bahwa manusia adalah properti, serta makhlukmakhluk pengumpul harta yang saling bersaing. ${ }^{10}$ Berangkat dari pemikiran mereka berdua, diyakini bahwa manusia diciptakan untuk menentukan nasibnya sendiri. Sayangnya, pemikiran seperti ini kemudian diterapkan pada mekanisme pasar yang juga diyakini akan berjalan sedemikian rupa dalam menentukan arahnya sendiri. Akibatnya, pasar menjadi tempat pertarungan orang-orang yang memiliki modal dalam memperebutkan keuntungan. Korban dari pertarungan itu bukanlah para pemilik modal, melainkan orangorang yang misalnya karena kegagalan panen membuat mereka berada pada posisi yang lemah. Orang-orang yang lemah ini pada gilirannya menjadi bagian dari komoditas dalam mekanisme pasar. Mereka disejajarkan dengan tanah, yang pada akhirnya dianggap sebagai properti dan bisa diperdagangkan dan

$8 \quad$ Ulrich Duchrow, Mengubah Kapitalisme Dunia: Tinjauan Sejarah-Alkitabiah Bagi Aksi Politis, terj. Esther Kuntjara (Jakarta: BPK Gunung Mulia, 2000), 11-70.

$9 \quad$ Ibid.

$10 \quad$ Ibid. 
ditambah terus jumlahnya. Dengan kata lain, peran manusia direndahkan menjadi bagian dari modal usaha.

Kondisi sebagaimana di sebut di atas, menurut Duchrow semakin parah ketika uang yang tadinya diharapkan menjadi alat tukar praktis dalam kegiatan ekonomi yang bertujuan memenuhi kebutuhan hidup, berubah menjadi simbol dan wujud keuntungan yang diraih. Akhirnya, tujuan ekonomi bergeser menjadi kegiatan dalam rangka mendapatkan dan menimbun uang sebanyakbanyaknya. ${ }^{11}$

Pada bagian selanjutnya, Duchrow juga menjelaskan bahwa menguatnya ekonomi pasar bebas dalam sistem kapitalis ternyata didukung oleh peran negara. ${ }^{12}$ Keterlibatan negara dalam hal ini adalah mengatur sistem kepemilikan, penggunaan properti, keuangan, dan kebijakan berkenaan dengan perdagangan luar negeri. Negara pada gilirannya terlibat sebagai yang turut berebut dalam mengumpulkan keuntungan. Di sinilah politik dan ekonomi berkolaborasi dalam menentukan ke mana tatanan masyarakat dibentuk. Pemahaman ini menentang pandangan yang menyatakan bahwa dalam faham kapitalisme pemerintah sama sekali tidak ikut campur dalam mekanisme pasar.

Dari uraian Duchrow ini, dapat disimpulkan bahwa di balik faham kapitalisme terkandung motivasi pengumpulan harta sebanyak-banyaknya. Motivasi ini terejawantah dalam kegiatan ekonomi dan mekanisme pasar yang pada gilirannya membuat manusia sebagai bagian dari modal, yang diyakini sebagai tumpuan pengumpulan harta sebanyak-banyaknya. Akibatnya, relasi manusia dengan sesama ciptaan Allah, baik manusia maupun alam, bisa saja dihargai atau dinilai berdasarkan kepentingan pengumpulan harta. Pertanyaannya adalah apakah situasi seperti ini sudah ada pada masa penulisan Injil Matius dan mempengaruhi penulisan Injil tersebut?

\section{ANTIOKHIA SEBAGAI KONTEKS INJIL MATIUS}

Awalnya, Injil Matius dianggap sebagai injil tertua yang ada dalam Alkitab, dan ditulis langsung oleh murid Yesus yang bernama Matius. ${ }^{13}$ Ia menulis injilnya

$11 \quad$ Ibid.

$12 \quad$ Ibid

13 Gerd Theissen, Gospel Writing and Church Politics: A Socio-rhetorical Approachs, Chuen King Lecture Series 3 (Hongkong: Theology Division, Chung Chi College, 2001), 46. 
bagi orang-orang Yahudi dengan menggunakan bahasa Ibrani. Pandangan ini terutama mengacu pada tulisan Ireneaus pada akhir abad kedua ZB. ${ }^{14}$ Pandangan ini kemudian bergeser setelah digunakannya pendekatan kritik-historis dalam penafsiran Alkitab. Berdasarkan pendekatan ini disimpulkan bahwa Injil Matius kemungkinan besar ditulis di luar Palestina, tepatnya di Antiokhia, Siria. ${ }^{15}$ Ada beberapa alasan sehingga pergeseran ini terjadi. ${ }^{16}$ Pertama, kutipan-kutipan paling awal dari Injil Matius ditemukan dalam tulisan Igantius dari Antiokhia pada permulaan abad kedua ZB. Dia menggunakan ayat-ayat yang hanya ada dalam Injil Matius dalam suratnya kepada beberapa gereja. Kedua, sebuah tulisan yang disebut Didache, yang berasal dari masa yang sama dengan suratsurat Ignatius dari Antiokhia, juga mengutip ayat-ayat dari Injil Matius, tepatnya Doa Bapa Kami versi Injil Matius, dan bukan dari Lukas. Sama seperti suratsurat Ignatius dari Antiokhia, Didache adalah tulisan yang dianggap berasal dari wilayah Antiokhia. Ketiga, Matius 4:24 secara eksplisit merujuk wilayah Siria sebagai tempat pelayanan Yesus. Penyebutan ini menjadi khas karena pada bagian lainnya dari Injil tersebut lebih menekankan pelayanan Yesus di kotakota di Galilea. Sementara itu, penyebutan Siria sebagai tempat pelayanan Yesus tidak ada dalam Markus 1:28 sebagai ayat paralelnya. Berdasarkan kritik-sumber dan juga analisa kritik-redaksi maka penyebutan Siria dianggap memiliki peran penting dalam motif penulisan Injil tersebut, yakni hubungan komunitas Matius dengan tempat itu. Keempat, peran Petrus dalam Injil ini sangat penting. Ia disebut sebagai salah seorang murid yang pertama dipanggil untuk mengikut Yesus (Mat. 4:18-20). Ia disebut pertama kali dalam urutan dua belas murid Yesus (Mat. 10:2). Ia mengikuti Yesus berjalan di atas air (Mat. 14:28-32). Ia juga murid yang mengakui Yesus sebagai Mesias, anak Allah yang hidup, sehingga Yesus menganugerahkan dia kunci kerajaan sorga (Mat 16:16-18); salah seorang dari tiga murid yang menjadi saksi peristiwa pemuliaan Yesus (Mat. 17:1-8). Akhirnya, ia juga yang menemani Yesus di taman Getsemane. Dan walaupun dia bukan orang pertama yang dikisahkan menerima penampakkan Yesus setelah kebangkitan, tetapi ia berperan dalam kisah penyaliban Yesus (Mat 26:33-35, 58, 69-75). Penokohan Petrus ini sangat mungkin terkait dengan peran Petrus, yang menurut Gal. 2:11-14, adalah tokoh penting di jemaat Aniokhia.

\footnotetext{
$14 \quad$ Ibid.

15 Warren Carter, Matthew and Empire: Initial Exploration (Harrisburg, Pennsylvania: Trinity Press International, 2001), 9 ..

16 Udo Schnelle, The History and Theology of The New Testament Writings (London: SCM Press, 1998), 222. Warren Carter, Matthew and The Margins, 14-16.
} 
Persoalan berikutnya adalah waktu bilamana Injil Matius ditulis. ${ }^{17}$ Dengan adanya kutipan teks-teks Injil Matius dalam surat-surat Ignatius dari Antiokhia dan Didakhe maka Injil Matius kemungkinan ditulis sebelum abad kedua ZB. Dengan asumsi bahwa Injil Matius mengambil sumbernya antara lain dari Injil Markus, serta rujukan terhadap kehancuran Bait Allah di Yerusalem pada tahun 70 ZB maka kemungkinan Injil Matius ditulis tidak lama setelah itu; kemungkinan sekitar satu atau dua dekade sesudahnya. Dengan kata lain, Injil Matius diperkirakan ditulis pada sekitar tahun 80-90 ZB. Pertanyaannya adalah apakah akar-akar kapitalisme di kekaisaran Romawi, termasuk wilayah Antiokhia pada akhir abad pertama ZB dapat ditemukan? Untuk menjawab pertanyaan ini maka perlu ditelusuri bagaimana kondisi kekaisaran Romawi pada waktu itu.

\section{KEKAISARAN ROMAWI DAN AKAR-AKAR KAPITALISME}

Kekaisaran Romawi berdiri pada tahun 27 SZB dengan Octavianus sebagai pemimpin yang bergelar Kaisar Augustus. Pada masa kepemimpinannya ia membangun jalan-jalan dan menetapkan berbagai kebijakan yang membuat perdagangan, termasuk perdagangan budak, menjadi sangat berkembang. ${ }^{18}$ Kepiawaiannya ini membawa Romawi sampai pada puncak keemasannya. Walaupun kaisar-kaisar sesudahnya tidak sepiawai Augustus, namun kekaisaran Romawi tetap kokoh terutama dua abad pertama setelah masa berdirinya. Namun demikian, beberapa perkembangan yang memprihatinkan juga muncul seiring masa keemasan Romawi. ${ }^{19}$ Korupsi dan kemerosotan moral lainnya merebak. Ketimpangan sosial semakin parah seiring menguatnya sekelompok kecil orang kaya berkuasa, yang berhadapan dengan sebagian besar masyarakat yang dibebani berbagai tanggungan pajak. Mereka yang kaya dan berkuasa semakin semena-mena bertindak karena memanfaatkan jasa militer untuk menumpuk kekayaannya. Kondisi ini tercermin dalam Injil-injil, misalnya percakapan Yohanes Pembaptis kepada para pemungut cukai dan prajurit-prajurit (Luk. 3:12-14), kisah bendahara yang tidak jujur (Luk. 16:1-9), perseteruan tuan tanah dengan para penggarapnya (Mrk. 12:1-12; Mat. 21:32-46; Luk. 20:9-20).

18 Norman Perin \& Dennis C. Duling, The New Testament: An Introduction, Second Edition ( NY: Harcourt Brace Jovanovich. Inc, 1982), 6. 
Di Antiokhia, kekuasaan Romawi tercermin dalam tiga hal penting, yakni politik ekonomi dan kebudayaan. ${ }^{20}$ Dalam bidang politik, Antiokhia merupakan ibu kota provinsi Siria, dan merupakan kota ketiga terbesar setelah Roma dan Aleksandria. Hubungan antara pemerintah pusat di Roma dengan Antiokhia begitu dekat. Tercatat beberapa kaisar pernah mengunjungi Antiokhia, misalnya Augustus, Tiberius dan Caligula. Sedangkan Trayanus yang saat menjadi kaisar mengunjungi Antiokhia tahun 70-an ZB, adalah anak dari seorang gubernur Siria. Kunjungan para kaisar ini semuanya bermuatan politis dan berkaitan dengan unjuk kekuatan, sekaligus mengukuhkan kekuasaan Romawi. Seiring dengan hal ini, sebagai ibu kota provinsi maka kehadiran gubernur sebagai pemimpin wilayah dengan sendirinya menjadi alat kepentingan pemerintah Romawi. Setiap gubernur biasanya dipilih oleh anggota Parlemen atau Majelis Tinggi, yang dikenal dengan sebutan senator. Kesetiaan gubernur terhadap pemerintah pusat di Roma antara lain ditunjukkan dengan pengumpulan pajak dan upeti yang lancar. Artinya, pengumpulan harta ada di balik relasi Antiokhia dengan Roma.

Jika di Roma terdapat kaum senator maka di Antiokhia terdapat Dewan Kota. ${ }^{21}$ Persyaratan baik untuk menjadi senator maupun anggota Dewan Kota adalah kekayaan. Jika untuk menjadi senator seseorang paling sedikit memiliki kekayaan senilai 250.000 dinar, atau setara dengan dua ratus lima puluh ribu kali upah pekerja harian dalam sehari, maka untuk menjadi anggota Dewan Kota seseorang setidaknya memiliki kekayaan senilai 25.000 dinar. ${ }^{22}$ Fungsi utama dari Dewan Kota adalah memilih dan menetapkan orang-orang yang mengurusi hal-hal yang terkait dengan kepentingan kota, misalnya taman dan gedung-gedung kesenian. Tugas-tugas orang-orang yang dipilih tersebut dinamakan liturgy atau pelayanan untuk kota. ${ }^{23}$ Walaupun tugas-tugas tersebut tidak menghasilkan upah kecuali prestise, namun demikian kekayaan memainkan peran penting, sebab dalam prakteknya hanya orang-orang kaya yang dipercaya untuk tugas-tugas tersebut. ${ }^{24}$

Di samping adanya Dewan Kota, di setiap kota, khususnya kota-kota helenis seperti Antiokhia, terdapat dua lembaga resmi yang diijinkan oleh pemerintah Romawi, yakni boule dan ekklesia. ${ }^{25}$ Lembaga-lembaga ini ada karena masyarakat

\footnotetext{
20 Bdk. Warren Carter, Matthew and Empire, 37-45.

21 Bdk. James M. Anderson, Women, Class, and Society in Early Christianity ( Peabody, Massachusetts: Hendrickson Publishers, 1997), 14-44.

22 Ibid.

23 Ibid.

24 Ibid.

25 Ibid.
} 
helenis memang menyukai sesuatu yang bersifat demokratis. Boule terdiri dari para bouletai atau para pemilik tanah yang kaya, sedangkan ekklesia umumnya terdiri dari kaum laki-laki yang memiliki kewarga-negaraan Romawi. Kedua lembaga tersebut secara teoritis adalah sarana untuk menyampaikan aspirasi politik masyarakat, tetapi kenyataannya hal itu tidak terjadi. Pemerintah Romawi merasa riskan jika masyarakat umum turut campur dalam pengelolaan negara. Oleh sebab itu pemerintah lebih mempercayakan urusan legislatif dan eksekutif hanya kepada kelompok kaya saja, yakni boule. Dengan kata lain maka dapat disimpulkan bahwa kondisi politik yang ada di Antiokhia sangat ditentukan oleh keberadaan orang-orang yang kaya, yang tiada lain adalah orang-orang yang memiliki kekuatan modal cukup untuk bersaing di arena publik.

Sedangkan dalam bidang ekonomi dua hal menonjol yang mencerminkan kekuasaan Romawi di Antiokhia ialah praktik pengumpulan pajak dan diberlakukannya uang-uang logam yang dikeluarkan oleh pemerintahan Romawi. ${ }^{26}$ Pemberlakuan pajak sebagaimana telah disinggung di atas bertalian dengan tanda ketaatan para pejabat di daerah terhadap pemerintah pusat di Roma. Kegagalan mengumpulkan pajak dan membayar upeti dengan lancar dianggap sebagai sebuah pemberontakkan. Sementara itu penggunaan uang-uang logam oleh pemerintah Romawi di Antiokhia tidak hanya berlaku sebagai alat tukar dalam transaksi ekonomi, tetapi juga bertalian dengan kepentingan politik Romawi. Gambar ataupun tulisan yang ada di uang logam pada waktu itu digunakan untuk mengukuhkan kekuasaan Romawi. Salah satu uang logam yang ada pada waktu itu bertuliskan "YUDEA CAPTA". Tulisan ini mengingatkan kemenangan Romawi atas Yudea pada tahun 70 ZB. Tulisan tersebut juga dipahami sebagai peringatan kepada siapapun untuk tidak melakukan pemberontakkan terhadap Romawi. Dengan kata lain dapat dikatakan bahwa ada hubungan yang tak terpisahkan antara kegiatan ekonomi dengan kepentingan politik, dan semuanya itu lebih melayani kepentingan orang-orang kaya yang berkuasa. Situasi ini semakin parah dengan kehadiran empat legiun tentara Romawi di Antokhia yang tidak hanya berfungsi mengawal kekuasaan Romawi dari ancaman kaum pemberontak, tetapi juga memperlancar proses pengumpulan pajak dan upeti.

26 Bdk. Warren Carter, Matthew and Empire, 35-46. 
Di bidang kesenian dan kebudayaan, kekuasaan Romawi hadir di Antiokhia melalui berbagai bangunan gedung, patung dan gerbang-gerbang. ${ }^{27}$ Selain dibangun gedung-gedung yang umumnya ada di kota-kota kuno waktu itu, di Antiokhia juga dibangun gedung-gedung untuk menunjukkan dan memperkokoh kekuasaan Romawi, seperti gedung administrasi dan pertahanan negara. Sementara itu patung-patung dan gerbang-gerbang juga sengaja dibangun untuk menampilkan kehadiran kekuasaan Romawi, misalnya patung Remus dan Romulus, serta patung Tiberius. Yang menjadi persoalan dari semua bangunan ini adalah dana yang digunakan untuk membuatnya. Kemungkinan besar bangunan-bangunan itu didanai dari hasil pajak baik yang dipungut dari rakyat di Syiria ataupun dari tempat lainnya di wilayah kekaisaran Romawi. Dari mana pun asalnya, yang pasti bangunan-bangunan itu lebih melayani kepentingan penguasa Romawi dan kroninya ketimbang masyarakat luas.

Dari ketiga hal tersebut di atas maka dapat disimpulkan bahwa Antiokhia merupakan salah satu kota helenis yang sunguh-sungguh dirancang untuk mencerminkan kekuasaan Romawi. Kondisi ini berpengaruh secara langsung terhadap semakin meningkatnya kekuatan orang-orang yang memiliki modal besar untuk menunjukkan eksistensinya. Di sisi lain keberadaan orang-orang miskin juga bertambah mengingat semakin banyak juga orang yang tertarik unuk mengadu nasib di sana. Para petani kecil dan penggarap tanah yang ada di wilayah pinggiran semakin sulitkehidupannya.Mereka dipaksa untukmemenuhi kebutuhan orang-orang kaya yang ada di pusat kota. Ketimpangan ekonomi masyarakat ini diceritakan antara lain oleh Philostratus yang mengisahkan kedatangan Apollonius ke kota Aspendus namun tidak menemukan apapun di pasar kerena orang-orang kaya telah menutup dan memborong seluruh bahan makanan yang ada untuk diekspor ke wilayah lain. ${ }^{28}$ Situasi ini benar-benar mencerminkan ironi menguatnya akar-akar masyarakat kapitalis. Segala sesuatu ditentukan oleh dan untuk kepentingan para pemiliki modal.

\section{MINORITAS MILITAN DI ANTIOKHIA}

Perlawanan komunitas Matius terhadap akar-akar kapitalisme tercermin dalam perlawanannya terhadap kekuasaan Romawi yang terbukti telah mem- 
bangun akar-akar kapitalisme, khususnya masyarakat yang dikuasai serta ditentukan oleh dan untuk kepentingan orang-orang yang memiliki modal besar. Pertanyaanya adalah siapa sesungguhnya komunitas Matius ini?

Ada pandangan yang menyatakan bahwa orang-orang Kristen mula-mula sepenuhnya terdiri dari orang-orang miskin..$^{29}$ Namun demikian pandangan ini ditentang oleh banyak ahli, pertama kali oleh E.A.Judge yang menyatakan bahwa orang-orang Kristen mula-mula terdiri dari berbagai golongan..$^{30}$ Pandangan ini diikuti juga oleh Gerd Theissen yang menjelaskan adanya beberapa lapisan orang Kristen. ${ }^{31}$ Di samping adanya para pekabar Injil yang berkeliling dari satu tempat atau kota ke tempat atau kota lainnya, ada juga di antaranya adalah para penyandang dana yang kemungkinan menjadi pemimpin lokal di jemaatjemaat mula-mula. Pemahaman-pemahaman ini didukung oleh data-data dalam Alkitab seperti Roma 16 yang menyebutkan tokoh-tokoh jemaat seperti Yunia yang berperan sebagai patron untuk jemaat rumahnya. ${ }^{32}$ Demikian juga dengan 1 Korintus 11:17-34 yang mencerminkan adanya ketidak-harmonisan dalam perkumpulan jemaat di Korintus yang terdiri dari orang-orang yang kaya dan miskin. ${ }^{33}$ Dengan kata lain dapat dikatakan bahwa komunitas gereja mula-mula, termasuk kemungkinan besar komunitas Matius di Antiokhia terdiri dari berbagai lapisan masyarakat, baik yang kaya maupun miskin. Jika memang demikian keadaannya apakah mungkin sebagai sebuah kelompok lintas status mereka sama-sama sepakat menolak pola kehidupan yang ditentukan oleh harta benda? Untuk menjawab pertanyaan ini maka penting juga dicermati jumlah keberadaan mereka dibandingkan dengan masyarakat di Antiokhia secara keseluruhan.

Dengan memanfaatkan berbagai hasil rekonstruksi terkait perkiraan jumlah orang Kristen di Antiokhia, baik dengan memperhitungkan jumlah maksimal orang-orang yang berkumpul sebagai jemaat rumah dalam satu rumah seorang patron, maupun dengan memperkirakan tingkat pertumbuhan penduduk dan jumlah keseluruhan orang Kristen pada akhir abad pertama ZB, maka secara nominal didapatkan angka sembilan belas sampai dua ratus orang Kristen yang ada di kota Antiokhia. ${ }^{34}$ Jika ini benar maka apabila dibandingkan dengan jumlah seluruh penduduk di Antiokhia yang berkisar antara 150.000-200.000

K. Kautsky, The Foundation of Christianity (NY: Russel \& Russel, 1953), 1-28.

E.A. Judge, The Social Pattern of Christian Groups in the First Century (London: Tyndale, 1960), 52-61.

Gerd Theissen, Sociology of Early Palestinean Christianity (Philadelphia: Fortress Press, 1978), 7-23.

Richard Bauckham, Gospel Women, 161-164.

Gerd Theissen, The Social Setting of Pauline Christianity (Philadelphia: Fortress Press, 1982), 145-174.

Warren Carter, Matthew and the Margins, 28-29. 
orang, ${ }^{35}$ jumlah ini relatif kecil. Mereka adalah kelompok minoritas. Namun demikian, walaupun mereka kecil dari sisi jumlah tetapi dapat dikatakan mereka sebagai kelompok yang cukup percaya diri dengan keberadaan diri mereka. Hal ini terungkap dalam relasi mereka dengan otoritas sinagoge yang menaungi jauh lebih banyak jumlah anggotanya ketimbang mereka. Diperkirakan pada paruh kedua abad pertama jumlah orang Yahudi di Antiokhia sekitar 45.000 jiwa. ${ }^{36}$ Dalam relasinya dengan otoritas sinagoge pada waktu itu mereka berani mengklaim sebagai kelompok yang lebih benar dalam memahami Taurat. Mereka mengklaim sebagai orang-orang Yahudi yang sejati. Silsilah yang ada dalam permulaan Injil tersebut mengekspresikan klaim identitas mereka sebagai orang-orang Yahudi. ${ }^{37}$ Sementara itu sebutan-sebutan negatif terhadap orangorang Farisi dan ahli-ahli Taurat menunjukkan keberanian mereka mengklaim bahwa tafsiran mereka tentang Taurat lebih benar daripada otoritas sinagoge pada waktu itu. ${ }^{38}$ Catatan ini penting untuk menunjukkan kemungkinan mereka sebagai kelompok yang berani menunjukkan identitas dan prinsip hidup mereka di hadapan mayoritas yang lebih besar, termasuk masyarakat di bawah pengaruh kekuasaan Romawi.

Perlawanan mereka terhadap kekuasaan Romawi antara lain diungkapkan oleh beberapa ahli seperti Michael Mann, Luke Johnson dan Rodney Stark. ${ }^{39}$ Sebagaimana dijelaskan oleh Carter, Mann berpendapat bahwa pendudukan Romawi di Antiokhia menimbulkan ketegangan atau kontradiksi yang tidak dapat diselesaikan. Pemerintah Romawi mengklaim sebagai yang menghadirkan berbagai kemudahan bagi seluruh masyarakat. Namun klaim tersebut tidak menjadi kenyataannya. Berbagai kemudahan yang ada hanya dinikmati oleh orang-orang kaya saja. Demikian juga dengan janji tersedianya partisipasi segenap warga masyarakat dalam mengatur hidup bersama. Semuanya tidak terjadi sesuai dengan yang diharapkan. Segala sesuatu lebih ditentukan oleh sekelompok elit orang kaya dan berkuasa. Menurut Mann, komunitas Matius secara ironis menggunakan pola yang digunakan pemerintah Romawi dalam mengklaim janji-janji tersebut tetapi melalui komunitas alternatif gerakan Yesus. ${ }^{40}$ Sementara itu Johnson lebih menyoroti fenomena munculnya berbagai

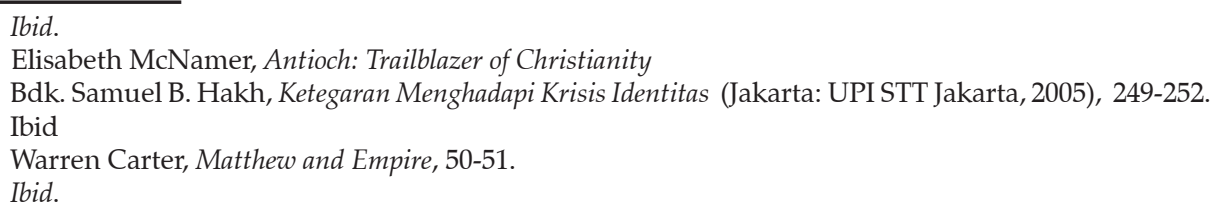


gerakan keagamaan, khususnya di wilayah timur kekaisaran Romawi. ${ }^{41}$ Gerakan-gerakan keagamaan ini mencerminkan semangat helenis sebagai reaksi ketidakpuasan terhadap kondisi sosial, politik dan keagamaan di wilayah kekuasaan Romawi. Injil Matius, menurut Johnson adalah tulisan dari komunitas Matius yang merupakan salah satu gerakan keagamaan yang mendambakan perubahan. Sedangkan Stark lebih menghubungkan munculnya komunitas Matius sebagai reaksi atas kemiskinan, kelaparan dan berbagai kondisi buruk akibat penjajahan Romawi melalui persekutuan yang memperhatikan dan sungguh-sungguh berusaha memenuhi kebutuhan orang-orang yang menjadi korban dari pendudukan Romawi. ${ }^{42}$ Dari ketiga pandangan ini semakin jelas bahwa Injil Matius muncul sebagai bentuk reaksi ketidakpuasan dari sebuah komunitas terhadap berbagai akibat buruk dari kekuasaan Romawi, termasuk menguatnya akar-akar kapitalisme di tengah masyarakat.

\section{PERLAWANAN KOMUNITAS MATIUS TERHADAP KAPITALISME}

Teks pertama yang dapat diajukan sebagai petuntuk perlawanan komunitas Matius terhadap akar-akar kapitalisme adalah kisah pencobaan Yesus di padang gurun (Mat. 4:1-11). Persoalan utama yang dibahas melalui kisah ini tampaknya adalah masalah kepatuhan. ${ }^{43}$ Siapa sesungguhnya yang menentukan tindakan Yesus? Kesetiaan atau kepatuhan kepada Allah ataukah sesuatu yang ada di luar Allah, yang dalam hal ini adalah kehendak Iblis. Dalam kisah ini tidak dijelaskan siapa Iblis sesungguhnya, tetapi dari tiga pencobaan yang ada tampaklah siapa sesungguhnya yang dimaksud, yakni kekuatan yang berlawanan dengan kehendak Allah. Jika kehadiran Yesus dipahami sebagai personifikasi karakter yang harus ditampilkan komunitas Matius maka kisah ini memberi petunjuk tentang karakter kepatuhan komunitas Matius yang harus dilakukan, yakni kepatuhan kepada Allah.

Berbeda dengan Markus yang hanya menyebut Yesus tinggal di padang gurun selama empat puluh hari dan dicobai Iblis, Matius dan Lukas menambahkannya dengan tiga bentuk pencobaan terhadap Yesus. Dalam kisah ini, Matius menempatkan pencobaan yang berhubungan dengan kerajaan dunia dan

$41 \quad$ Ibid.

$42 \quad$ Ibid.

43 Ibid., 106. 
kemegahannya di urutan terakhir setelah pencobaan mengenai kebutuhan makanan dan menjatuhkan diri dari bubungan Bait Allah. Urutan ini berbeda dengan Lukas yang menempatkan pencobaan mengenai kerajaan dunia dan kemegahannya di urutan kedua setelah pencobaan yang berhubungan dengan makanan (Luk. 4:1-13). Perbedaan urutan ini akan dapat dimengerti dengan memperhatikan persoalan-persoalan yang tampaknya melatarbelakangi munculnya kedua injil tersebut. Bagi Matius, persoalan mengenai kebenaran ajaran orang Farisi dan ahli-ahli taurat lebih ditekankan ketimbang godaan harta benda. Dibandingkan dengan Injil-injil lainnya, Matius lebih bersikap negatif terhadap para pemimpin agama, khususnya orang-orang Farisi dan para ahli Taurat. Bubungan Bait Allah tampaknya dipakai sebagai simbol kehadiran para tokoh agama tersebut. Sementara itu, bagi Lukas, persoalan mengenai harta benda lebih menonjol daripada persoalan tentang kebenaran pengajaran para pemuka agama Yahudi itu. Walaupun begitu tetap perlu diperhatikan bahwa pencobaan mengenai kerajaan dunia dan segala kemegahannya itu menjadi bagian penting dari pencobaan yang harus dilalui Yesus.

Bukti bahwa bagi Matius harta benda sebagai bagian dari kemegahan kerajaan dunia tetap menjadi godaan yang harus diatasi antara lain adalah pengajaran Yesus dalam khotbah di bukit, dalam hal mengikut Yesus serta kisah pengutusan murid-murid Yesus. Salah satu pengajaran dalam khotbah Yesus di bukit yang melawan motivasi pengumpulan harta ada dalam doa yang diajarkan Yesus (Mat. 6:9-13), khususnya ayat 11, "Berikanlah kami pada hari ini makanan kami yang secukupnya". Teks ini mengingatkan pada kisah dalam Perjanjian Lama tentang perintah Allah berkenaan dengan pengumpulan manna (Kel. 16). ${ }^{44}$ Ini adalah bentuk perlawanan terhadap keserakahan, yang dipahami telah mengubah peran pasar dan tujuan kegiatan ekonomi yang seharusnya melayani kepentingan orang banyak menjadi alat pengumpul keuntungan bagi pribadi dan kelompok. Pemahaman ini sejalan dengan apa yang disampaikan dalam Amsal 30:8, "Jauhkanlah dari padaku kecurangan dan kebohongan. Jangan berikan kepadaku kemiskinan atau kekayaan. Biarkanlah aku menikmati makanan yang menjadi bagianku." Teks ini juga perlu dipahami dengan memperhatikan Mazmur 146:7 dan Yesaya 58:6-7, yang mengajarkan pentingnya berbagi berkat makanan bagi orang-orang yang miskin dan kelaparan. ${ }^{45}$

44 Warren Carter, Matthew and the Margins, 167-168.

$45 \quad$ Ibid. 
Pengajaran Yesus selanjutnya yang penting diperhatikan sebagai bentuk perlawanan terhadap akar-akar kapitalisme adalah hal mengumpulkan harta (Mat. 6:19-21). Di dalamnya Yesus menjelaskan dua jenis harta, yakni di bumi dan di sorga. Perhatikanlah perbedaan teks ini dengan paralelnya di Lukas 12:33-34. Matius menggunakan kata bumi untuk mengkontraskannya dengan di sorga. Bumi adalah tempat tinggal dan tempat manusia beraktivitas dan bekerja untuk memenuhi kebutuhan hidupnya sehari-hari. Mengapa para pengikut Yesus dilarang mengumpulkan harta di bumi? Tiada lain karena bumi sudah dipenuhi dengan kejahatan. Walaupun disebutkan juga bahwa bumi adalah tumpuan kaki Allah (Mat. 5:35), kefanaan adalah karakternya (Mat. 5:18). Bisa jadi ini merujuk pada kebiasaan manusia yang dikuasai oleh keserakahan. Sebaliknya, sorga adalah tempat kediaman Allah. Hal ini juga telah tampak dalam rumusan doa yang Yesus ajarkan, "Bapa kami yang di sorga" (Mat. 6:9). Yang dimaksud dengan tempat di sini bukanlah sebuah ruang, melainkan situasi dan kondisi ketika Allah hadir dan bertahta. Yesus menganjurkan agar para pengikutnya lebih mengejar harta di sorga daripada harta di bumi. Artinya, komunitas Matius memang diarahkan untuk menampilkan pola kehidupan alternatif yang tidak dikuasai oleh semangat pengumpulan harta sebagaimana masyarakat di bawah kekaisaran Romawi, melainkan lebih melakukan segala sesuatu sesuai dengan kehendak Allah, yakni berbagi berkat dengan sesama.

Pemahaman sebagaimana disebut di atas dilanjutkan dalam pengajaran tentang kekuatiran (Mat. 6:25-34), khususnya ayat 33, “Tetapi carilah dahulu Kerajaan Allah dan kebenarannya, maka semuanya itu akan ditambahkan kepadamu." Pengajaran Yesus mengenai kekuatiran sebenarnya merefleksikan kondisi sosial masyarakat, termasuk juga komunitas Matius sendiri yang mungkin terdiri dari orang-orang kaya dan orang-orang miskin. ${ }^{46}$ Di dalamnya berisi tantangan bagi orang-orang yang kaya untuk lebih menggantungkan hidup hanya kepada Allah, sekaligus dukungan bagi orang-orang miskin untuk tidak terpancing oleh godaan yang mendorong manusia dikuasai harta benda. Selain itu penting juga untuk diperhatikan bahwa ayat 33 hanya ada dalam Injil Matius. Artinya, ayat ini semakin menunjukkan karakter radikal komunitas alternatif Matius.

Kisah berikutnya yang penting untuk diperhatikan adalah hal mengikut Yesus (Mat. 8:18-22). Di dalamnya ada dua hal penting yang ingin disampaikan,

$46 \quad$ Warren Carter, Matthew and the Margins, 176. 
yakni otoritas Yesus sebagai utusan Allah dan beratnya resiko yang harus diambil untuk menjadi pengikut Yesus. Namun demikian di sinilah salah satu karakter komunitas Matius hendak dinyatakan. ${ }^{47}$ Sebuah karakter yang tidak terpengaruh oleh godaan untuk memburu upah dan harta di dunia. "Serigala mempunyai liang dan burung mempunyai sarang, tetapi Anak Manusia tidak mempunyai tempat untuk meletakkan kepala-Nya." (Mat. 8:20). Karakter komunitas Matius ini ditegaskan lagi dalam kisah pengutusan murid-murid Yesus (Mat. 10:5-15), khususnya ayat 8b-10. Perhatikanlah perbedaan teks ini dari paralelnya baik di Markus dan Lukas! Matius menggunakan kata-kata emas dan perak sebagai ganti uang, serta menambahkan kata upah. Emas dan perak merupakan barang-barang berharga yang juga dipakai untuk alat tukar. Artinya, komunitas Matius adalah komunitas yang secara sadar menolak untuk menampilkan kemewahan dan serta ketergantungan pada harta duniawi. Dengan kata lain, perintah Yesus dalam Matius 10:5-15 bukan hanya masalah strategi untuk mendapatkan akses berhubungan dengan orang-orang miskin, ${ }^{48}$ tetapi merefleksikan prinsip ketergantungan mutlak komunitas Matius kepada kehendak Allah dalam bentuk melawan motivasi mencari keuntungan dengan menjual nama Allah, dan tampil mewah.

Karakter komunitas Matius terlihat semakin kuat tercermin dalam nubuat mengenai penganiayaan yang akan dialami oleh murid-murid Yesus dan kehadiran Yesus yang membawa pemisahan (Mat. 10:16-42). Kedua nubuat ini tidak hanya dapat dipahami dalam relasi komunitas Matius dengan otoritas sinagoge, tetapi juga kekuasaan Romawi dan akar-akar faham kapitalisme yang semakin menguat. Keduanya menampilkan perlawanan radikal komunitas Matius terhadap struktur masyarakat tersebut.

\section{MUDA BANYAK HARTANYA ${ }^{49}$}

Perlawanan terhadap motif pengumpulan harta di balik faham kapitalisme sangat kuat ditampilkan dalam kisah mengenai orang muda yang banyak hartanya. Sebelum masuk dalam kisah mengenai orang kaya yang banyak hartanya, Matius

Ibid., 207.

Ibid.

Bdk. Demianus Nataniel, "Sejak Muda Berjaya, Mati Masuk Surga”, dlm. Wawasan, Oktober-November 2012, 55-56. 
mengisahkan Yesus yang memberkati anak-anak (Mat. 19:13-15). Di sini karakter komunitas Matius yang pro terhadap orang-orang yang menjadi korban struktur yang lebih menguntungkan orang-orang kaya dan berkuasa dinyatakan. Anakanak dapat dipahami sebagai kelompok masyarakat yang lemah dan tidak berdaya melawan kekuatan kapitalis yang mulai menggeliat.

Kisah ini diawali dengan kedatangan seseorang kepada Yesus, dan mengajukan sebuah pertanyaan,"Guru, perbuatan baik apakah yang harus kuperbuat untuk memperoleh hidup yang kekal?" Perhatikanlah harapan yang tersirat dalam ucapan orang tersebut! Dengan tegas ia ingin meraih apa yang disebut dengan "hidup yang kekal". Apa maknanya? Dalam Perjanjian Lama, frasa "hidup yang kekal" digunakan dalam Daniel 12:2. Dalam teks tersebut, hidup yang kekal dihubungkan dengan apa yang akan diterima oleh sebagian orang yang sudah mati di akhir zaman. Dalam kitab 4 Makabe frasa ini juga muncul. Kemunculannya tersebut tampaknya berhubungan kisah martir Eleazar dan tujuh orang bersaudara, dan itu artinya sangat mungkin berhubungan dengan sesuatu setelah kematian. Dalam Perjanjian Baru kesan mengenai hubungan frasa 'hidup yang kekal' dengan kehidupan setelah kematian juga muncul. Misalnya Luk. 18:30, “... dan pada zaman yang akan datang ia akan menerima hidup yang kekal." Jika memang makna frasa "hidup yang kekal" berhubungan dengan keadaan setelah kematian maka artinya ia tengah membayangkan sekaligus bercita-cita meraih sesuatu yang bukan ada dalam kehidupan di dunia ini. Mengapa dia menginginkan ini? Apa yang terjadi padanya? Untuk menjawab ini kita perlu tahu siapa sebenarnya dia.

Berdasarkan uraian di atas maka pemahaman mengenai "hidup yang kekal" bertumpu pada keyakinan adanya kebangkitan orang mati. Pemahaman ini muncul sebagai reaksi terhadap kenyataan banyaknya orang saleh yang meninggal dengan cara yang mengenaskan. Keyakinan akan kebangkitan orang mati adalah keyakinan yang berkembang di kalangan Farisi. ${ }^{50}$ Dan hal ini berbeda dari kaum Saduki yang tidak meyakini adanya kebangkitan orang mati. ${ }^{51}$ Jika orang Farisi dalam Injil Matius mendapatkan kesan negatif maka artinya Matius tengah menampilkan sisi buruk orang tersebut.

Karakter lainnya yang disebutkan oleh Matius tentang orang itu adalah sebutan "muda" dan "banyak hartanya". Sebutan "muda" hanya ada dalam Matius.

$50 \quad$ Norman Perrin \& Dennis C. Duling, The New Testament: An Introduction, 31.

$51 \quad$ Ibid. 
Markus dan Lukas sama sekali tidak menyebutkan orang itu sebagai yang muda. Kata-kata "orang muda" di sini harus dipahami bukan semata-mata dari sisi usia. Pemahaman Yudaisme abad pertama yang kuat mewarnai alam pikiran Matius memaknai kata "muda" sebagai karakter yang menunjukkan kekuatan, energi, semangat atau kegairahan yang meluap-luap, sebagaimana yang digambarkan antara lain dalam Amsal, "Hiasan orang muda ialah kekuatannya, dan keindahan orang tua ialah uban." (Ams. 20:29). Lalu apa artinya jika dia kemudian disebut orang yang banyak hartanya. Kata Yunani yang digunakan menyebut hartanya di sini adalah kth,mata $k t \square m a t a$ dengan akar kata $k t \square m a$, yang merujuk pada properti, khususnya tanah yang bernilai ekonomis. Dalam terjemahan LXX kata yang sama persis dipakai untuk menyebutkan kebun-kebun anggur (Hos. 2:17 dan Y1 .1:11). Artinya, kemungkinan besar ia adalah seorang tuan tanah yang secara sadar atau tidak waktu itu dikuasai oleh akar-akar semangat kapitalisme yang berambisi terus menumpuk kekayaan. Usaha untuk menumpuk kekayaan membuat mereka melihat segala sesuatu, termasuk sesamanya manusia dalam kaca mata untung-rugi. Pertemanan dan persaudaraan ditentukan dengan apakah secara ekonomis menguntungkan atau tidak. Akibatnya, mereka seringkali mendapat julukan orang yang kejam seperti yang diungkapkan oleh seorang pegawai yang hanya dipercaya mengusahakan satu talenta (Mat. 25:24), atau bahkan memicu pemberontakan oleh orang-orang yang merasa hanya dimanfaatkan saja seperti para penggarap kebun anggur (Mat. 21:33-39).

Dari gambaran di atas maka kita dapat simpulkan bahwa orang yang dimaksud oleh Matius adalah seorang tuan tanah yang sangat berambisi. Hanya saja, kali ini ambisinya agak lain. Ia ingin menjelajahi bukan hanya sesuatu yang sudah dimiliki di dunia ini, tetapi juga yang akan dapat dinikmati setelah kematiannya nanti. Untuk meraih keinginannya ini, ia bertanya kepada Yesus. Perhatikan kekhasan pertanyaannya. Dalam Markus dan Lukas, kata "baik" berkaitan dengan karakter Yesus, "Guru yang baik, apa yang harus aku perbuat untuk memperoleh hidup yang kekal?" Sedangkan dalam Matius, kata "baik" dilekatkan kepada perbuatan yang seharusnya dilakukan, "Guru, perbuatan baik apakah yang harus kuperbuat untuk memperoleh hidup yang kekal?". Artinya, Matius memang menekankan perbuatan yang benar-benar ingin diketahui oleh seorang tuan tanah yang penuh ambisi ini. Kata "baik" (agathos) yang dilekatkan pada "perbuatan" tidak hanya bermakna ideal berkaitan dengan etika dan estetika, tetapi juga dipakai untuk perbuatan yang efektif, 
efisien, bahkan pragmatis. Dengan kata lain, orang itu bertanya mengenai perbuatan yang benar-benar pas, cocok, bermanfaat, pasti menghasilkan, tokcer, jitu , untuk meraih "hidup yang kekal". Tujuan ini belum tentu menggambarkan secara positif orang tersebut, tetapi lebih menampilkan karakter ambisius orang itu. Dan menurut Yesus, ambisinya ini keliru. Salah! Apa buktinya?

Jawaban Yesus menunjukkan bahwa keinginan tuan tanah yang ambisius itu keliru. Jika orang itu bertanya dalam rangka meraih "hidup yang kekal", maka Yesus mengarahkannya agar ia mendapatkan "hidup" dan kemudian "sorga". Kata "hidup" dan "sorga" dalam konteks Injil-injil lebih merujuk pada kehidupan di dunia ini, yang dicirikan dengan Allah sebagai pusat segalanya. Kata "hidup" tidak semata-mata berbicara mengenai kondisi ketika seseorang masih bisa bernafas. Kata ini memiliki makna relasi dengan Allah. Seseorang walaupun masih bisa bernafas namun tidak memiliki relasi yang baik dan benar dengan Allah dapat dikatakan mati. Sebagaimana manusia-manusia pertama yang melanggar perintah Allah untuk tidak makan buah pengetahuan yang baik dan benar. Setelah mereka memakan buah itu mereka tetap bernafas, mampu melakukan sesuatu, bersembunyi dan beralasan di hadapan Allah. Padahal Allah sudah memvonis mereka dengan sebutan "mati". Sementara itu sorga adalah kediaman Allah, dan bumi adalah tempat manusia. Namun demikian, Allah juga menginjakkan kaki-Nya di bumi, "karena bumi adalah tumpuan kaki-Nya" (Mat. 5:35). Dengan Allah sebagai pusat dari segalanya maka manusia menempatkan diri sebagai yang sama-sama melayani untuk memuliakan Allah di dunia ini. Kondisi inilah yang diyakini akan menghadirkan damai sejahtera bagi semua orang. Inilah berita suka cita itu. Ini berbeda dengan makna "hidup yang kekal" yang mengacu pada kehidupan setelah kematian. Dengan kata lain Yesus mendorong orang itu perduli pada kehidupan di dunia ini ketimbang rebut-ribut soal kehidupan setelah kematian nanti.

Sikap Yesus sebagaimana disebut di atas ditegaskan dengan menyarankan agar orang itu menjual seluruh kepunyaannya, dan hasilnya diberikan untuk membantu orang-orang yang miskin. Itulah yang terbaik! Berbuat sesuatu di dunia ini untuk orang-orang yang ada di dunia ini, khususnya mereka yang menjadi korban sistem yang dikuasai oleh semangat untuk menjadi yang paling kaya, paling sukses dan berkuasa! Jelas, apa yang dianjurkan oleh Yesus ditanggapi dengan sedih dan kecewa oleh orang itu. Ia sulit melakukannya. Hartanya telah menguasai dirinya. Ia tidak rela kehilangan itu semua. 
Dari seluruh uraian di atas maka dapat disimpulkan bahwa kehadiran orang muda yang banyak hartanya adalah personifikasi ambisi penumpukkan harta di balik faham kapitalisme. Mereka yang dikuasai oleh ambisi ini tidak lagi peka dengan lingkungannya, dengan orang-orang miskin di sekitarnya. Pikiran dan perasaan mereka melanglang buana memikirkan sesuatu yang hanya untuk kesenangan sendiri. Ucapan Yesus dengan demikian dapat dimaknai sebagai prinsip hidup komunitas Matius yang melawan secara keras faham kapitalisme tersebut.

\section{PENUTUP}

Injil Matius merupakan karya sebuah komunitas Kristen di kota Antiokhia, Siria pada akhir abad pertama ZB. Karya ini mengekspresikan karakter komunitas tersebut dalam menghadapi situasi dan kondisi lingkungannya. Situasi dan kondisi yang mempengaruhi pesan-pesan dalam Injil Matius bukan hanya pertentangan dengan otoritas sinagoge yang dipersonifikasikan dalam tokoh orang-orang Farisi dan para ahli Taurat, tetapi juga akar-akar kapitalisme yang mulai menggeliat seiring menguatnya kekuasaan Romawi di Antiokhia. Akar-akar faham kapitalisme yang begitu kuat dilawan adalah keserakahan dan tindakan penumpukkan harta. Akibat keserakahan yang ada di balik tindakan penumpukkan harta adalah pengabaian terhadap keberadaan orang-orang miskin yang semakin hari semakin bertambah banyak.

Komunitas Matius adalah komunitas alternatif yang dibangun bukan hanya untuk melawan pola kehidupan yang dikuasai oleh keserakahan dan diperbudak oleh harta, tetapi juga adalah komunitas yang menawarkan cara hidup yang sungguh-sungguh peka dan perduli kepada korban sistem sosial yang menyengsarakan banyak orang. Dalam menyatakan pandangan hidup dan keyakinannya, komunitas Matius dapat dikatakan sebagai kaum minoritas yang militan. Pandangannya radikal dan tanpa kompromi. Mereka berani dan siap menghadapi risiko apapun yang mungkin terjadi, termasuk ancaman bagi keselamatan jiwa mereka.

Karakter komunitas Matius yang militan dalam menjalankan prinsip hidup dan keyakinannya tercermin dalam berbagai kisah dalam Injil Matius. Perbedaan beberapa bagian dari teks Injil Matius yang memiliki paralelnya dengan Injil Markus dan Lukas semakin menunjukkan karakter militan komunitas Matius. 
Radikalitas komunitas Matius dalam menjalankan prinsip hidup dan keyakinannya tentu tidak dapat dipisahkan dari tekanan berat yang dirasakan oleh komunitas tersebut. Walaupun di antara mereka kemungkinan adalah orangorang yang kaya, namun itu tidak menutup mata hati mereka untuk mau perduli terhadap penderitaan yang ada di sekitarnya.

Sikap komunitas Matius sebagaimana disebutkan di atas penting untuk dicermati dan dihayati oleh gereja di mana pun saat ini, mengingat ideologi kapitalisme seolah-olah tidak dapat dibendung sama sekali. Keserakahan yang diwujudkan dalam perilaku mengumpulkan harta tanpa perduli nasib sesama ciptaan Allah adalah pengalaman hidup sehari-hari yang jelas-jelas harus disikapi dengan tegas. Ekspresi yang ditampilkan oleh komunitas Matius melalui Injilnya ini mengingatkan pada pendapat Duchrow yang mengingatkan bahwa tidak ada upaya untuk meraih kebebasan dan solidaritas yang tidak berbenturan dengan sistem ekonomi, politik dan ideologi yang anti kehidupan. ${ }^{52}$ Tanpa keberanian mengambil risiko untuk berbenturan dengan sistem yang mendominasi sulit diharapkan akan adanya perubahan yang diharapkan. Namun demikian, gereja rasanya tidak perlu berkecil hati. Sejarah dunia telah menunjukkan bahwa sistem yang sudah mendarah daging seperti perbudakan pun bisa dihapuskan. Demikian pula dengan pengalaman keberhasilan perjuangan gerakan oikoumenis yang dilakukan Dewan Gereja Sedunia dalam menghapuskan sistem Apartheid di Afrika Selatan. Semuanya adalah petunjuk bahwa tidak ada yang mustahil untuk dapat dilakukan jika itu didasarkan pada kesungguhan dan ketaatan pada kehendak Allah. Ingatlah yang dikatakan oleh Yesus dalam Matius 19:26: Yesus memandang mereka dan berkata: "Bagi manusia hal ini tidak mungkin, tetapi bagi Allah segala sesuatu mungkin."

$52 \quad$ Ulrich Duchrow, Mengubah Kapitalisme Dunia, 231. 


\section{DAFTAR PUSTAKA}

Arlandson, J.M., Women, Class, and Society in Early Christianity, Peabody, Massachusetts: Hendrickson Publishers, 1997.

Bauckham, R., Gospel Women: Studies of Named Women in the Gospels, London, New York: T\&T Clark, 2002.

Carter, W., Matthew and the Margins: A Sociopolitical and Religious Reading, NY: Orbis Books, 2000.

--------- ., Matthew and Empire: Initial Exploration, Harrisburg, Pennsylvania: Trinity Press International, 2001.

Duchrow, U., Mengubah Kapitalisme Dunia: Tinjauan Sejarah-Alkitabiah Bagi Aksi Politis, terj. Esther Kuntjara, Jakarta: BPK Gunung Mulia, 2000.

Judge, E.A., The Social Pattern of Christian Groups in the First Century, London: Tyndale, 1960.

Nataniel, D., "Sejak Muda Berjaya, Mati Masuk Surga”, dlm. Wawasan, OktoberNovember 2012.

Theissen, G., Gospels Writing and Church Politics: A Socio-rhetorical Approachs, Chuen King Lecture Series 3, Hongkong: Theology Division, Chung Chi College, 2001.

------------., The Social Setting of Pauline Christianity, Philadelphia: Fortress Press, 1982.

., Sociology of Palestinean Christianity, Philadelphia: Fortress Press, 1978.

Hakh, S.B., Ketegaran Menghadapi Krisis Identitas, cetakan kedua, Jakarta: UPI STT Jakarta, 2005.

Perrin, N., \& Dennis C. Dulling, The New Testament: An Introduction, Second Edition, NY: Harcourt Brace Jovanovich, Inc, 1982.

Rhoads, D., "Social Criticism", dalam Mark \& Methods: New Approaches in Biblical Studies, peny. Jenice C. Anderson \& Stephen D. Moore, Minneapolis: Fortress Press, 1992.

Schnelle, U., The history and Theology of The New Testament Writings, London: SCM Press, 1992.

Simmons, B., "The Internationalization of Capital", dalam Continutiy and Change in Contemporary Capitalism, peny. K. Kitschelt, P. Lange, G. Marks \& D. 
Stephens, Cambridge: Cambridge University Press, 1999.

Soros, G., Open Society: Reforming Global Capitalism, terj. Sri Koedyantinah, Jakarta: Yayasan Obor Indonesia, 2006.

Weber, M., The Protestant Ethic And The Spirit of Capitalism, trans. Talcott Parsons, New York: Charles Scribner's Sons, 1958. 
54 JURNAL ABDIEL - APRLL 2017 